\title{
Perlakuan Terhadap Sesama Ditinjau Dari Teori Humanistik
}

\author{
Devi Devi, Dewi Agustina Lahang, Feby Noveni, Jenilin J., \\ Liviaavis L.
}

\begin{abstract}
Abstrak
Perlakuan terhadap orang lain adalah bagaimana sikap kita terhadap orang yang ada di sekitar kita baik orang yang dekat dengan kita maupun orang yang tidak kita kenal sekalipun, yang memiliki status terpandang maupun orang yang tidak mempunyai status terpandang, orang yang layak maupun orang yang tidak layak. Apapun keadaannya dan di manapun keberadaannya, semua manusia pastinya ingin di hargai dan di hormati atau saling memanusiakan antar sesama kita. Manusia pada dasarnya memiliki naluri untuk memperoleh penghargaan dan kepedulian dari orang lain dan kepeduliannya juga terhadap orang yang ada disekitarnya. Oleh karena itu, maka tujuan dari penelitian ini adalah: pertama,untuk menjelaskan tentang perlakuan Yesus terhadap orang yang sakit kusta dalam Lukas 5:12-16. Kedua, menjelaskan implikasi perlakuan terhadap sesama kita berdasarkan Lukas 5:12-16 bagi orang yang ada pada zaman ini. Kesimpulan yang di peroleh dari hasil menganalisis Lukas 5:12-16 adalah: pertama, penghargaan yang dilakukan Yesus terhadap orang yang sakit kusta tersebut dengan cara mengasihi dia dan memberikan kehidupan yang baru terhadap orang kusta itu. Kedua, Yesus mau menjamah orang yang sakit kusta itu dan mentahirkan dia dari sakit kustanya. Ketiga, Yesus menyuruh supaya ia mempersembahkan korban pentahiran dari kenajisan, supaya orang kusta itu bisa di terima kembali di dalam masyarakat dimana dia berada. Karena dalam konteks ajaran agama Yahudi orang yang sakit dianggap dihukum Tuhan sehingga di jauhi oleh banyak orang, dipandang begitu buruk dan tidak dianggap orang lain.
\end{abstract}

Kata-kata kunci: perlakukan, sesama, humanistik, Yesus 


\section{PENDAHULUAN}

\section{Latar belakang masalah}

Perlakuan adalah bagaimana cara kita kepada orang lain, baik atau buruk, menghargai atau tidak, membeda-bedakan orang lain atau tidak dan bagaimana cara pandang kita terhadap orang lain. semua orang pasti punya kerinduan untuk di perlakukan dengan baik oleh orang yang ada disekitnya apakah itu orang yang dekat dengan dia ataupun orang asing yang ada disekitanya. Perlakuan menyangkut tentang perasaan seseorang dan menyangkut juga tentang kebutuhan fisik dan rasa aman yang terpenuhi dengan baik, maka akan muncul kebutuhan akan cinta, kasih sayang, dan rasa dimiliki. Kebutuhan akan cinta melibatkan pemberian dan penerimaan kasih sayang. Dan ketika orang tersebut tidak mendapat atau merasakan perlakuan tersebut maka orang tersebut akan merasa tidak memiliki dukungan dan kehilangan orang-orang yang ada di sekitanya yang selalu mendukung dia.

Jika seseorang yang mendapa perlakuan tidak menyenangkan atau tidak di perlakukan sebagaimana mestinya maka cenderung seseorang akan menghindar dan berdia diri. Kesulitan memercayai orang lain dalam pergaulannya sehari-hari dan akan menutup diri dari orang lain. Kita bisa melihat keadaan di lingkungn kita sendiri dimana kadang-kadang ada orang yang tersisihkan dan tidak mendapatkan perlakuan yang baik dari seseamanya. Apalagi di zaman yang modern dan canggih ini dan perkembangan zaman yang tersu menerus terjadi sehingga orang kadang-kadang tidak peduli terhadap perasaan orang lain dan langsung menghina atau menghakimi orang lainn tanpa mengetahui kebenarannya terlebih dahulu.

Kasih terhadap sesama sudah semakin kurang akhir-akhir ini. manusia lebih mementingkan kehidupan pribadi dibandingkan memperhatikan orang yang lainnya. Tidak mempunyai rasa kepedulian lagi terhadap sesama dan hanya berfokus kepada diri sendiri saja. Apa yang terjadi di lingkungan sekitar kita kadang-kadang tidak ada lagi yang peduli karena mengganggap itu bukan urusan saya dan tidak mau repot dengan apa yang sedang terjadi. Melihat dan mengetahui keadaan orang lain mungkin sulit untuk di terapkan pada zaman ini, karena kehidupan sosial kita juga sudah tergantikan oleh kehidupan media-media yang digunakan untuk berkomunikasi dengan orang lain.

Dilihat dari nas alkitab dalam Lukas 5:12-16, perlakuan Yesus terhadap sesama memberikan contoh yang baik kepada kita bahwa apapun keadaan orang yang ada di sekitar kita baik orang yang kita kenal maupun orang yang tidak kita kenal, jika ia membutuhkan pertolongan maka kita harus bersedia menolong orang itu seperti yang dilakukan oleh Yesus. Apa yang dilakukan Yesus sebenarnya sangat berbahaya pada saat itu karena orang yang najis dijauhi supaya kenajisannya tidak tertular dan orang yan tahir tidak boleh menyentuh orang yang najis agar dia juga tiak cemar oleh kenajisan orang tersebut. Namun kita bisa melihat bahwa semua orang berhak untuk di perlakukan dengan baik meskipun dalam keadaan yang buruk sekalipun.

Dalam teori Abraham Maslow yaitu Humanistik atau memanusiakan manusia, Yesus memberikan contoh yang baik bagi kita untuk memperlakukan sesama kita denga baik. orang yang memiliki sakit kusta itu telah di perlakukan dengan baik olehYesus dengan cara menyebuhkan dia dari penyakitkustanya. Sehingga ia boleh menjadi tahir dan menjadi orang yang bisa di terima kembali. Dalam lingkungan kita pasti ada orang yang merasakan hal seperti itu juga, merasa tidak di terima dalam masyarakat dimana dia berada. Perlakuan kita terhadap orang lain pasti akan mempengaruhi sikap dari orang tersebut. 
Semua orang pasti ingin merasa aman dilingkungan di manapun dia berada itulah sifat manusia yang ingin dihargai dan dihormati sama seperti orang lain pada umumnya. Teori humanistik adalah teori yang memanusiakan manusia artinya menyetarakan manusia yang satu dengan manusia yanag lainnya. perlakuan terhadap sesama memberikan dampak yang besar baik perlakuan yang positif maupun perlakuan yang negatif. Tanggapan atau respon dari seorang manusia yang di perlakukan dengan baik akan memberikan dampak yang baik pula bagi orang tersebut, sebaliknya jika seseorang mendapat perlakuan yang buruk dia akan sulit untuk percaya kepada orang yang ada di sekitarnya.

Menghargai dan mengasihi orang lain adalah perlakuan yang tepat bagi sesama kita. memang kadang-kadang sulit untuk memperlakukan orang lain dengan benar karena terkadang keegoisan kita lebih tinggi dibandingkan dengan kasih kita. Namun kita harus sadar juga akan keberadaan orang-orang yang ada di sekitar kita. mengasihi dan menghargai orang lain adalah cara terbaik kita memperlakukan mereka sama seperti orang pada umumnya. Didalam masyarakat pasti kita akan menemui orang-orang yang dianggap paling rendah dan paling hina sama seperti orang kusta itu, namun Yesus telah mengajari kita untuk peduli dan mengasihi orang-orang yang tersisihkan seperti orang kusta itu. Orang-orang yang tidak dianggap dan seperti sampah masyarakat memang selalu dipojokkan oleh masyarakat yang mengganggap diri mereka suci dan bersih.

Perlakuan tidak baik bisa juga terjadi karena perbedaan suku dan agama, namun kita harus sadar bahwa kita adalah ciptaan Tuhan dan di mata Tuhan kita semua adalah mahluk yang sama dan sederajat. Tidak ada yang lebih tinggi dan tidak ada yang lebih rendah. Perlakuan yang adil dan beradab adalah perlakuan yang sama untuk semua orang tanpa terkecuali. Menghargai setiap hak-hak kemanusiaan semua orang secara sama dan sederajat tanpa ada pandangan orang yang rendah dan orang yang tinggi. Tuhan saja mampu menghargai kita manusia yang berdosa, bagaimana bisa kita sebagai mahluk ciptaannya tidak bisa mengasihi dan memperlakukan sesama kita dengan baik.

Kasih yang Yesus tunjukkan kepada kita menjadi contoh yang patut kita teladani didalam memperlakukan sesama kita dengan baik. Yesus tidak meihat orang itu dari pandangan yang rendah dan kotor tetapi Yesus melihatorang kusta itu sebagai orang yang berharga dan patut mendapat perlakuan yang baik. Didalam kita memperlakukan sesama kita harus ada kasih yang kita miliki. Karena jia kita tidk memiliki kasih maka tidak mungkin kita bisa memperlakukan orang-orang yang ada disekitar kita dengan baik. kasih terhadap sesamalah yang mendorong kita untuk memperlakukan sesama kita dengan baik karena kita merasa bahwa semua orang patut untuk mendapatkan hal itu.

Kita harus melakukan hal yang sama seperti Yesus lakukan yaitu memperlakukan orang yang rendah dan tidak dianggap sekalipun dengan baik dan penuh kasih tanpa menuntut balas dari orang tersebut. Apa yang kita lakukan mungkin dianggap tidak berrti bagi orang lain dan dianggap rendah oleh orang lain. Tetapi sebagai manusia perlakuan terhadap sesama manusia memang sangat penting karena kita juga pasti ingin di perlakukan dengan baik oleh orang yang ada disekitar kita. Dunia akan terasa lebuh baik jika kita bisa memperlakukan sesama kita dengan baik. 


\section{Kajian Teori}

\section{Teori Ivan Pavlov}

Prosedur Conditioning Pavlov disebut Classic karena merupakan penemuan bersejarah dalam bidang psikologi. Secara kebetulan Conditioning refleks (psychic refleks) ditemukan oleh Pavlov pada waktu ia sedang mempelajari fungsi perut dan mengukur cairan yang dikeluarkan dari perut ketika anjing (sebagai binatang percobaannya) sedang makan. Ia mengamati bahwa air liur keluar tidak hanya pada waktu anjing sedang makan, tetapi juga ketika melihat makanan. Jadi melihat makanan saja sudah cukup untuk menimbulkan air liur. Gejala semacam ini oleh Pavlov disebut "Psychic" refleks. Conditioning adalah suatu bentuk belajar yang memungkinkan organisme memberikan respon terhadap suatu rangsang yang sebelumnya tidak menimbulkan respon itu, atau suatu proses untuk mengintroduksi berbagai reflek menjadi sebuah tingkah laku. Jadi classical conditioning sebagai pembentuk tingkah laku melalui proses persyaratan (conditioning process). Dan Pavlov beranggapan bahwa tingkah laku organisme dapat dibentuk melalui pengaturan dan manipulasi lingkungan. Untuk menunjukkan kebenaran teorinya, Pavlov mengadakan eksperimen tentang berfungsinya kelenjar ludah pada anjing sebagai binatang ujicobanya. ${ }^{1}$ Teori Ivan Pavlov ini menujukan bahwa apa yang menjadi eksperimen yang dilakukan menimbulkan stimulus dan respons terhadap eksperimen tersebut. Dalam implikasi teori Ivan Pavlov ini dalam pembelajaran disekolah ketika memberikan pengajaran kepada peserta didik, seorang pengajar tidak banyak untuk menjadikan peserta didik menjadi objek dalam kelas, tetapi seorang pendidik perlu untuk menjadi subjek di dalam kelas sehingga tidak hanya pendidik yang menjadi objek tapi semuanya berperan di dalam kelas.

\section{Alasan Mengambil literatur Nas Alkitab}

Alasan kami memilih nas ini karena dalam kehidupan sehari-hari kita melihat begitu banyak sifat atau karakter orang yang berbeda-beda dan tanpa disadari bahwa menjadi dampak bagi orang lain. Dalam perilaku yang baik artinya perilaku yang setiap orang mampu untuk menjadikan orang lain merasakan dampak perilaku yang baik kepada orang. Dari cerita Alkitab atau nas yang kami ambil untuk menjadikan materi dalam pembelajaran humanistik, dapat dilihat bahwa Tuhan Yesus tidak memilih orang karena Ia mengasihi semua orang. Ia datang bagi milik kepunyaanNya.

Perilaku yang baik akan memengaruhi pertumbuhan rohani yang lebih baik. ${ }^{2}$ Perilaku yang baik mencerminkan karakter yang baik. Karakter dibentuk di keluarga, sekolah, dan masyarakat. ${ }^{3}$ Karakter Kristus adalah karakter yang mengasihi Bapa. Dia bertindak apa yang diehendaki oleh Bapa. Yesus memandang manusia yang

${ }^{1}$ Titin Nurhidayati, "Implementasi Teori Belajar Ivan Petrovich Pavlov (Classical Conditioning) Dalam Pendidikan," Jurnal Falasifa ( Maret 2012):24.

${ }^{2}$ Jonathan Matheus and Elisabet Selfina, "Peran Pembina Remaja Bagi Perkembangan Perilaku Remaja Di Gereja Kemah Injil Indonesia Tanjung Selor Kalimantan Utara,” Jurnal Jaffray 13, no. 1 (January 31, 2015): 1-22, https://doi.org/10.25278/jj71.v13i1.3.

${ }^{3}$ Elsyana Nelce Wadi and Elisabet Selfina, "Peran Orang Tua Sebagai Keluarga Cyber Smart Dalam Mengajarkan Pendidikan Kristen Pada Remaja GKII Ebenhaezer Sentani Jayapura Papua,” Jurnal Jaffray 14, no. 1 (March 14, 2016): 77-92, https://doi.org/10.25278/jj71.v14i1.190. 
percaya sebagai manusia baru yang telah meninggalkan manusia lama. ${ }^{4}$ Yesus memandang orang yang berdosa sebagai kepedulian, tetapi membenci dosanya. Setiap orang mendapatkan kesempatan untuk mengenal Yesus dan percaya. Setiap orang berhak untuk menyembah Allah yang benar. Hal itupun dilakukan Yesus dengan perempuan yang dituduh kedapatan berzina. Ada juga perempuan berdosa di dekat sumur yang Yesus jumpai pada siang hari. Perempuan itu akhirnya percaya Yesus dan menjadi penyembah dalam Roh dan Kebenaran. ${ }^{5}$

\section{Hubungan Teori dan nas Alkitab}

Teori humanistik bagimana manusia memanusiakan manusia lain hubungannya dengan nas alkitab yang dipilih ialah bagaimana orang kusta mencari Yesus untuk kesembuhannya. dalam setiap kehidupan manusia kadang hanya mementingkan diri sendiri. Dapat kita lihat kasih Yesus kepada orang yang benar-benar ingin datang kepadanya peroleh kesembuhan yang kekal. Sesama manusia seharusnya saling mengasihi sesama ketika sesorang jatuh dalam dosa, terkadang orang memikirkan kesalahan orang tidak fokus pada niat hatinya yang ingin berubah.

Karakter Yesus menunjukkan kasih yang mendalam. Tujuan karakter adalah percaya dan takwa kepada Allah yang Esa. ${ }^{6}$ Bagaimana mungkin seseorang dapat mengasihi sesamanya tanpa mengasihi Allah Yang Es aitu? Memanusiakan manusia berarti menerima keberadaan manusia yang berdosa, tanpa mengabaikan dosa sebagai lawan Allah. Sebagai orang percaya pun melakukan hal yang sama yaitu membenci dosanya, mengasihi manusia sebagaimana Yesus memberikan contoh yang benar kepada umat-Nya.

\section{Metode}

Metode yang digunakan dalam penulisan ini adalah kajian kualitatif dengan membuat gagasan teori dan praktik di dalamnya dengan menjelaskan pokok-pokok pikiran dan gagasan/ide. ${ }^{7}$ Selanjutnya dengan menggunakan model pembelajaran Kooperatif ${ }^{8}$ dan memberikan motivasi belajar kepada mahasiswa untuk meningkatkan hasil belajar ${ }^{9}$ melalui metode belajar berarti berupa yaitu $5 \mathrm{P}$ (Penghubung, pelajaran, Penerapan, Perubahan, dan penutup). ${ }^{10}$ Selanjutnya diuraikan 5P di dalam praktik kelas

\footnotetext{
${ }^{4}$ Hengki Wijaya, "Pengenaan Manusia Baru Di Dalam Kristus: Natur, Proses, Dan Fakta Serta Implikasi Teologis Dan Praktisnya,” Jurnal Jaffray 14, no. 1 (March 22, 2016): 109, https://doi.org/10.25278/jj71.v14i1.194.

${ }^{5}$ Hengki Wijaya, "Kajian Teologis Tentang Penyembahan Berdasarkan Injil Yohanes 4:24," Jurnal Jaffray 13, no. 1 (March 16, 2015): 77, https://doi.org/10.25278/jj71.v13i1.112.

${ }^{6}$ Hengki Wijaya and Helaluddin Helaluddin, "Hakikat Pendidikan Karakter," 2018, https://repository.sttjaffray.ac.id/id/publications/269450/hakikat-pendidikan-karakter.

${ }^{7}$ Hengki Wijaya and Helaluddin Helaluddin, Analisis Data Kualitatif Sebuah Tinjauan Teori \& Praktik (Makassar: Sekolah Tinggi Theologia Jaffray Makassar, 2019).

${ }^{8}$ Hengki Wijaya and Arismunandar Arismunandar, "Pengembangan Model Pembelajaran Kooperatif Tipe STAD Berbasis Media Sosial,” Jurnal Jaffray 16, no. 2 (October 6, 2018): 175-96, https://doi.org/10.25278/jj71.v16i2.302.

${ }^{9}$ Sifra Sahiu and Hengki Wijaya, "Hubungan Motivasi Belajar Ekstrinsik Terhadap Hasil Belajar Psikomotorik Pada Mata Pelajaran Agama Kristen Kelas V Di SD Zion Makassar,” Jurnal Jaffray 15, no. 2 (September 22, 2017): 231, https://doi.org/10.25278/jj71.v15i2.262.

${ }^{10}$ Roland Walker, "Learning That LASTS," n.d., https://wycliffe.fi/wpcontent/uploads/2018/12/intro-to-learning-that-lasts-walker.pdf.
} 
dan melihat relevansi teori humanistik yang diintegrasikan dengan nilai-nilai karakter Kristus, dan diimplikasikan dalam kehidupan Kristen.

\section{Pembahasan}

Fokus: memperlakukan sesama kita dengan baik sama seperti diri kita sendiri (Lukas 5:12-16)

\section{Penghubung}

Perlakuan yang baik bagi sesama kita memang sangat penting dan pasti akan memberikan dampak yang positif bagi orang tersebut. Semua orang pasti ingin di kasihi dan diperlakukan dengan baik oleh orang lainnya. kita pasti merasa aman dan merasa kita dicintai oleh orang-orang yang berada disekitar kita jika kita di perlakukan dengan baik oleh orang lain sama seperti Yesus memperlakukan orang kusta itu dengan baik dengan caramenjamah dan mentahirkan dia dari sakit kustanya. Yang kita harus lakukan dan terapkan dari cerita ini yaitu kita harus mennghargai dan mengasihi orang-orang yang ada disekitar kita dimanapun keberadaannya dan apapun status mereka.

2. Pelajaran

Sama seperti orang kusta yang berusaha untuk di pulihkan oleh Yesus dengan cara datang dan berseru kepada Yesus. Kita juga harus berusaha untuk memperlakukan orang yang ada disekitar kita dengan baik tanpa melihat keadaan yang sedang ia alami.

3. Penerapan

Ketika kita ada di posisi yang tidak di perlakukan dengan baik atau tersisihkan maka pasti kita akan merasa sendiri dan tidak ada seorang pun yang mengasihi kita. kita pasti merasa bahwa hanya kita sendiir yang hidup di dunia ini dan tidak ada orang lain yang mempedulikan kita sehingga kita akan tersakiti dan akan menjadi orang yang sulit untuk pulih dan kita pastinya akan mengalami trauma yang panjang dengan orang-orang yang ada disekitar kita. maka dari itu kita harus berusaha memperlakukan orang lain sama seperti kita memperlakukan orang lain dengan baik dan benar. Kita tidak membeda-bedakan orang tetapi kita harus memandang semau orang sama seperti Tuhan memandang kita.

4. Perubahan

Ketika kita sedang berada didalam keadaan seperti itu maka kita akan cenderung cuek dan tidak mudah percaya kepada orang lain. hati kita akan tersakiti dan merasa bahwa apa yang kita alami tidak adil. Namun Tuhan sudah menunjukkan kasih yang begitu besar dan patut kita contoi dalam kehidupan kita. kita harus memiliki kesadaran bahwa orang lain juga ingin diperlakukan dengan baik oleh sesamanya sama seperti kita juga ingin di perlakukan dengan baik.

5. Penutup

Kita harus belajar mempraktekkan hal yang dilakukan oleh Yesus yaitu mengasihi orang yang ada disekitar kita. memperlakukan orang lain dalam keadaan apapun dengan baik sama seperti kasih Yesus kepada kita. 


\section{Hasil dan pembahasan}

Perlakuan terhadap orang lain memang sangat penting untuk dilakukan. Seseorang yang diperlakukan dengan baik akan memberikan dampak positif bagi orangorang yang ada disekitanya dan pasti akan melakukan hal yang sama yaitu memperlakukan orang lain dengan baik sama seperti apa yang telah ia alami. Sebaliknya orang yang tidak mendapat perlakuan yang baik pasti akan emberikan dampak yang negatif bagi orang yang ada disekitarnya. Apa yang kita lakukan, apa yang kita terima akan kita dapatkan kembali hasilnya. Selalu ada hasil yangkita peroleh dari apa yang kit alakukan baik itu positif maupun negatif. Kita juga harus memberikan atau membuat hal yang bisa membuat orang lain sadar akan perlakuan terhadap orang lain. sehingga orang lain juga mempunyai kesadaran dalam setiap diri kita untuk sadar dan memperlakukan orang lain dengan baik.

Pada dasarnya jika orang yang ada disekeliling kita diperlakukan dengan baik maka otomatis orang tersebut juga akan mampu dan bisa untuk memperlakukan orang yang ada disekitar mereka dengan baik. Tetapi jika kita tidak memperlakukan orang lain dengan baik maka otomatis semua hal yang dilakukan pastinya akan berdampak juga. Maka dari itu kita harus merubah dan memperlakukan orang lain dengan baik seperti diri kita sendiri.

\section{Kesimpulan}

Perlakuan terhadap sesama memang sangat penting bagi semua orang. Karena manusia selalu ingin diperlakukan dengan baik. Tuhan saja bisa memperlakukan kita manusia yang berdosa dengan baik, bagaimana mungkin kita tidak bisa memperlakukan sesama kita dengan baik. kita harus berubah dalam pandangan kita tentang sesama kita. semua orang perluh dan berhak untuk di perlakukan dengan baik. Manusia ingin memperoleh perlakuan yang baik dari orang orang yang ada disekitarnya, karena pada dasarnya manusia mempunyai naluri untuk dihargai dan dihormati. Arti sederhananya ialah bagimana manusia memperhatikan manusia lain dimanapun mereka berada dan apapun status mereka, tetap harus disamakan manusia dengan orang lain. Manusia dilahirkan pada dasarnya sudah peroleh kasih dari setiap orang tuanya dan melekat dalam diri manusia sampai kapanpun dan pasti ingin memperoleh terus menurus hal itu. 


\section{DAFTAR PUSTAKA}

Nurhidayati, Titin. "Implementasi Teori Belajar Ivan Petrovich Pavlov (Classical Conditioning) Dalam Pendidikan." Jurnal Falasifa (Maret 2012)

Matheus, Jonathan, and Elisabet Selfina. "Peran Pembina Remaja Bagi Perkembangan Perilaku Remaja Di Gereja Kemah Injil Indonesia Tanjung Selor Kalimantan Utara." Jurnal Jaffray 13, no. 1 (January 31, 2015): 1-22. https://doi.org/10.25278/jj71.v13i1.3.

Sahiu, Sifra, and Hengki Wijaya. "Hubungan Motivasi Belajar Ekstrinsik Terhadap Hasil Belajar Psikomotorik Pada Mata Pelajaran Agama Kristen Kelas V Di SD Zion Makassar." Jurnal Jaffray 15, no. 2 (September 22, 2017): 231. https://doi.org/10.25278/jj71.v15i2.262.

Wadi, Elsyana Nelce, and Elisabet Selfina. "Peran Orang Tua Sebagai Keluarga Cyber Smart Dalam Mengajarkan Pendidikan Kristen Pada Remaja GKII Ebenhaezer Sentani Jayapura Papua.” Jurnal Jaffray 14, no. 1 (March 14, 2016): 77-92. https://doi.org/10.25278/jj71.v14i1.190.

Walker, Roland. "Learning That LASTS," n.d. https://wycliffe.fi/wpcontent/uploads/2018/12/intro-to-learning-that-lasts-walker.pdf.

Wijaya, Hengki. "Kajian Teologis Tentang Penyembahan Berdasarkan Injil Yohanes 4:24." Jurnal Jaffray 13, no. 1 (March 16, 2015): 77. https://doi.org/10.25278/jj71.v13i1.112.

Wijaya, Hengki, and Arismunandar Arismunandar. "Pengembangan Model Pembelajaran Kooperatif Tipe STAD Berbasis Media Sosial." Jurnal Jaffray 16, no. 2 (October 6, 2018): 175-96. https://doi.org/10.25278/jj71.v16i2.302.

Wijaya, Hengki, and Helaluddin Helaluddin. Analisis Data Kualitatif Sebuah Tinjauan Teori \& Praktik. Makassar: Sekolah Tinggi Theologia Jaffray Makassar, 2019.

Wijaya, Hengki. "Hakikat Pendidikan Karakter," 2018. https://repository.sttjaffray.ac.id/id/publications/269450/hakikat-pendidikankarakter. 
